\title{
Article \\ Effect of Cobalt and Chromium Ions on the Chlorhexidine Digluconate as Seen by Intermolecular Diffusion
}

\author{
Sónia I. G. Fangaia ${ }^{1}$, Pedro M. G. Nicolau ${ }^{1}$, Fernando A. D. R. A. Guerra ${ }^{1}$, M. Melia Rodrigo ${ }^{2}$, \\ Gianluca Utzeri $^{3(D)}$, Ana M. T. D. P. V. Cabral ${ }^{4}$, Artur J. M. Valente ${ }^{3, * \mathbb{D}}$, Miguel A. Esteso ${ }^{2,5}$ (D) \\ and Ana C. F. Ribeiro ${ }^{3}$ D
}

\section{check for} updates

Citation: Fangaia, S.I.G.; Nicolau, P.M.G.; Guerra, F.A.D.R.A.; Rodrigo, M.M.; Utzeri, G.; Cabral,

A.M.T.D.P.V.; Valente, A.J.M.; Esteso, M.A.; Ribeiro, A.C.F. Effect of Cobalt and Chromium Ions on the Chlorhexidine Digluconate as Seen by Intermolecular Diffusion. Int. J. Mol. Sci. 2021, 22, 13266. https://doi.org/ 10.3390/ijms222413266

Academic Editor: Francesca Diomede

Received: 14 November 2021

Accepted: 6 December 2021

Published: 9 December 2021

Publisher's Note: MDPI stays neutral with regard to jurisdictional claims in published maps and institutional affiliations.

Copyright: (c) 2021 by the authors. Licensee MDPI, Basel, Switzerland. This article is an open access article distributed under the terms and conditions of the Creative Commons Attribution (CC BY) license (https:/ / creativecommons.org/licenses/by/ $4.0 /)$.
1 Institute of Implantology and Prosthodontics, Faculty of Medicine, University of Coimbra, 3000-075 Coimbra, Portugal; sfangaia@fmed.uc.pt (S.I.G.F.); pgnicolau@mail.telepac.com (P.M.G.N.); fguerra@ci.uc.pt (F.A.D.R.A.G.)

2 U.D. Química Física, Universidad de Alcalá, 28805 Alcalá de Henares, Spain; mmelia.rodrigo@uah.es (M.M.R.); mangel.esteso@ucavila.es (M.A.E.)

3 Department of Chemistry, CQC, University of Coimbra, 3004-535 Coimbra, Portugal; gianlucautz@gmail.com (G.U.); anacfrib@ci.uc.pt (A.C.F.R.)

4 Faculty of Pharmacy, CQC, University of Coimbra, 3000-295 Coimbra, Portugal; acabral@ff.uc.pt

5 Universidad Católica Santa Teresa de Jesús de Ávila, 05005 Ávila, Spain

* Correspondence: avalente@ci.uc.pt

\begin{abstract}
Metal ions such as cobalt (II) and chromium (III) might be present in the oral cavity, as a consequence of the corrosion of Co-Cr dental alloys. The diffusion of such metal ions into the organism, carried by saliva, can cause health problems as a consequence of their toxicity, enhanced by a cumulative effect in the body. The effect of the chlorhexidine digluconate, which is commonly used in mouthwash formulations, on the transport of these salts is evaluated in this paper by using the Taylor dispersion technique, which will allow an assessment of how the presence of chlorhexidine digluconate (either in aqueous solution or in a commercial formulation) may affect the diffusion of metal ions. The ternary mutual diffusion coefficients of metal ions ( $\mathrm{Co}$ and $\mathrm{Cr}$ ) in the presence of chlorhexidine digluconate, in an artificial saliva media, were measured. Significant coupled diffusion of $\mathrm{CoCl}_{2}$ (and $\mathrm{CrCl}_{3}$ ) and chlorhexidine digluconate is observed by analysis of the non-zero values of the cross-diffusion coefficients, $D_{12}$ and $D_{21}$. The observed interactions between metal ions and chlorhexidine digluconate suggest that the latter might be considered as an advantageous therapeutic agent, once they contribute to the reduction of the concentration of those ions inside the mouth.
\end{abstract}

Keywords: artificial saliva; cobalt chloride; chromium chloride; diffusion coefficients; chlorhexidine digluconate

\section{Introduction}

The use of metal alloys in the manufacture of dental prostheses has been a common practice for decades. Several dental alloys have been used in the fabrication of these devices, such as titanium alloys, cobalt-chromium alloys, chromium-nickel alloys, etc. Although these alloys are biocompatible and relatively resistant to corrosion, when exposed to certain media (e.g., acid environments [1,2]), and also as a consequence of wear [3] resulting from chewing, the release of metal ions in the oral cavity is a matter of concern. If these metal ions are constantly diffusing into body fluids, their concentration in the body will increase and, after a certain latency period, it can reach a toxic threshold value that can cause significant harmful effects on the body (by combining with biomolecules such as enzymes and proteins), leading to health problems [4,5].

The chromium released during the degradation of the Co-Cr alloys is essentially $\mathrm{Cr}(\mathrm{III})$, but it can be oxidized to $\mathrm{Cr}(\mathrm{VI})$ at the cellular level. $\mathrm{Cr}(\mathrm{VI})$ is mutagenic and carcinogenic, with its potential biological effects being controversial [6]. In any case, metals 
such as chromium and cobalt, which may have potential or demonstrated oncogenic effects in humans, must be subject to strict regulations for the protection of humans $[7,8]$.

The release of metal ions from orthodontic devices in the presence of mouthwashes is a matter of concern given the potential toxicity raise and function loss of devices [9-11].

Among those devices, prosthetic restorations are subject to fretting corrosion and wear [12-14], and the released wear debris may produce ionic species which have a potential toxicity depending on their concentration [15]. Consequently, it is of utmost importance to analyze the behavior of those ions in the oral cavity. There are several studies that identify released elements or determine ion concentrations $[2,15]$. However, to the best of our knowledge, the use of mass transport by diffusion to assess the interaction between metal ions and mouthwashes is an innovative approach.

In the present manuscript, the interaction between metal ions, in particular divalent cobalt and trivalent chromium ions, and a pharmacological molecule: chlorhexidine digluconate $\left(\mathrm{C}_{34} \mathrm{H}_{54} \mathrm{Cl}_{2} \mathrm{~N}_{10} \mathrm{O}_{14}\right.$, Figure 1) (CHDG), which is present in many mouthwashes, is evaluated by measuring intermolecular diffusion coefficients using the Taylor dispersion method [16-18]. We intend to conclude about the potential of CHDG to act as a carrier of those ions, facilitating their removal from the oral cavity and, thus, reducing the potential toxicity.<smiles>CCCCCCCNC(=N)NC(=N)NC(=N)Nc1ccc(Cl)cc1</smiles><smiles>COC[C@H](O)[C@@H](O)[C@H](O)[C@H](O)C(=O)O</smiles>

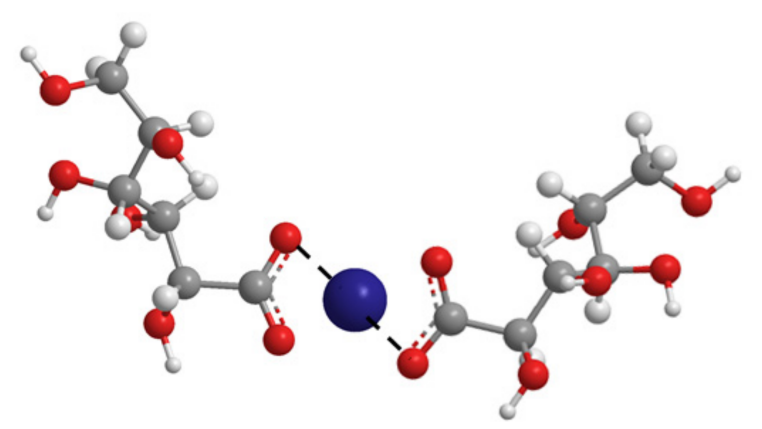

Figure 1. Chlorhexidine digluconate structure (top) and schematic representation of complexation between a divalent metal ion (e.g., $\mathrm{Co}^{2+}$, blue sphere) and digluconate (bottom).

It is known that a considerable decrease in salivary $\mathrm{pH}$ occurs after drinking acidic beverages whose $\mathrm{pH}$ is around $2[19,20]$, and several studies are related to the behavior of metal alloys under physiological conditions using a $\mathrm{pH}=2.3[1,21]$.

In the first part of this study, tracer diffusion coefficients, $D$, or apparent diffusion coefficients for aqueous solutions of cobalt (II) chloride and chromium (III) chloride at $0.001 \mathrm{~mol} \mathrm{dm}^{-3}$, in artificial saliva at $\mathrm{pH}$ : 8.3, 7.0, and 2.3, and in artificial saliva with sodium fluoride at $\mathrm{pH}=7.0$, are reported. This study is complemented by the evaluation of the diffusion behavior of the chlorhexidine digluconate (as a pure compound or contained in commercial formulation) in aqueous solution in the absence or presence of metal ions' salts. UV-visible spectroscopy was also used to assess the effect of chlorhexidine digluconate on $\mathrm{Co}(\mathrm{II})$ and $\mathrm{Cr}(\mathrm{III})$. 


\section{Results and Discussion}

Table 1 shows the tracer diffusion coefficients, $D^{0}{ }_{1}$, for aqueous solutions of cobalt (II) chloride and chromium (III) chloride in water and in CHDG-containing solutions. It can be seen that the $D^{0}{ }_{1}$ value for $\mathrm{CoCl}_{2}$ matches with that previously reported in [22] and measured by using the open-ended capillary cell. Although the tracer diffusion coefficients are similar for both salts, and for the mixture as well, at $\mathrm{pH} 6.4$, the predominant cationic species are $\mathrm{Co}^{2+}[23]$ and $\mathrm{Cr}_{3}(\mathrm{OH})_{4}{ }^{5+}$ [24]. It can also be seen that, in general, the tracer diffusion coefficients decrease by decreasing the solution $\mathrm{pH}$. In fact, the presence of GHDC either as pure or in a commercial formulation leads to a slight increase in the acidity of the media.

Table 1. Tracer diffusion coefficients, $D^{0}{ }_{1}$, of $\mathrm{CoCl}_{2}\left(0.001 \mathrm{~mol} \mathrm{dm}^{-3}\right), \mathrm{CrCl}_{3}\left(0.001 \mathrm{~mol} \mathrm{dm}^{-3}\right)$, and a mixture of $\mathrm{CoCl}_{2}$ and $\mathrm{CrCl}_{3}$ in different aqueous media, and the respective standard deviations of the mean ${ }^{(\mathrm{a})}, S_{D}$, at $T=298.15 \mathrm{~K}$ and $P=101.3 \mathrm{kPa}$.

\begin{tabular}{lcccc}
\hline & \multicolumn{3}{c}{$D^{\mathbf{0}}{ }_{\mathbf{1}} \pm \mathrm{S}_{\mathbf{D}} / \mathbf{( 1 0}^{-\mathbf{9}} \mathbf{~ m}^{\mathbf{2}} \mathbf{s}^{-\mathbf{1}} \mathbf{)}$} \\
\hline & $\mathbf{p H}$ & $\mathbf{C o C l}_{\mathbf{2}}$ & $\mathrm{CrCl}_{\mathbf{3}}$ & $\mathbf{C o C l}_{\mathbf{2}} / \mathbf{C r C l}_{\mathbf{3}}$ \\
\hline water & 6.4 & $1.295 \pm 0.010$ & $1.272 \pm 0.014$ & $1.189 \pm 0.015$ \\
0.2\% CHDG & 5.0 & $0.666 \pm 0.015)$ & $0.656 \pm 0.015$ & - \\
$\begin{array}{l}\text { CHDG commercial } \\
\text { formulation }\end{array}$ & 5.7 & $0.709 \pm 0.020)$ & $0.718 \pm 0.018$ & $0.915 \pm 0.022$ \\
\hline
\end{tabular}

(a) Averaged result for $\mathrm{n}=3$ experiments. Standard uncertainties, $u$, are $u_{\mathrm{r}}(C)=0.03, u(T)=0.01 \mathrm{~K}$, and $u(P)=2.03 \mathrm{kPa}$.

Table 2 shows the tracer diffusion coefficients of the same salts and mixture of salts in artificial saliva (AS). In order to evaluate the effect of ionic strength and $\mathrm{pH}$ on the tracer diffusion coefficients, we have used sodium fluoride and lactic acid, to control both parameters, respectively. The former has been chosen as it is an important component of several oral mouth rinses used for preventing dental caries $[25,26]$, whilst the latter has been used to simulate the variation of $\mathrm{pH}$ occurring in the oral cavity $[27,28]$.

Table 2. Tracer diffusion coefficients, $D^{0}$, of $\mathrm{CoCl}_{2}, \mathrm{CrCl}_{3}$, and a mixture of $\mathrm{CoCl}_{2}$ and $\mathrm{CrCl}_{3}$ in different artificial saliva (AS) media, at $T=298.15 \mathrm{~K}$ and $P=101.3 \mathrm{kPa}$.

\begin{tabular}{|c|c|c|c|c|}
\hline & \multicolumn{4}{|c|}{$D^{0}{ }_{1} \pm S_{D} /\left(10^{-9} \mathrm{~m}^{2} \mathrm{~s}^{-1}\right)^{(a)}$} \\
\hline & $\mathrm{pH}$ & $\mathrm{CoCl}_{2}$ & $\mathrm{CrCl}_{3}$ & $\mathrm{CoCl}_{2} / \mathrm{CrCl}_{3}$ \\
\hline AS & 8.3 & $1.823 \pm 0.024$ & $1.789 \pm 0.040$ & $1.890 \pm 0.045$ \\
\hline AS & 7.0 & $1.860 \pm 0.010$ & $1.808 \pm 0.020$ & $1.909 \pm 0.014$ \\
\hline AS + lactic acid & 2.3 & $0.921 \pm 0.030$ & $0.908 \pm 0.012$ & $0.917 \pm 0.010$ \\
\hline $\mathrm{AS}+\mathrm{NaF}$ & 7.0 & $1.701 \pm 0.029$ & $2.065 \pm 0.019$ & $2.315 \pm 0.020$ \\
\hline $\mathrm{AS}+$ lactic acid $+\mathrm{NaF}$ & 2.3 & $0.899 \pm 0.031$ & $0.782 \pm 0.030$ & $0.826 \pm 0.028$ \\
\hline
\end{tabular}

(a) Averaged result for $\mathrm{n}=3$ experiments. Standard uncertainties, $u$, are $u_{\mathrm{r}}(C)=0.03, u(T)=0.01 \mathrm{~K}$, and $u(P)=2.03 \mathrm{kPa}$.

Table 3 shows the average experimental diffusion coefficients of solutions of chlorhexidine digluconate $\left(D_{\text {CHDG }}\right)$. These values are compared with those obtained by using a CHDG-based commercial formulation ( $\left.D_{\text {CHDG-cf }}\right)$. It should be noted that information on apparent diffusion coefficients of CHDG in a commercial mixture is of significant importance for understanding the behavior of this compound in practical dental applications. The reproducibility of these diffusion coefficients is similar to that observed for other systems, i.e., within $\pm 2 \%[29,30]$. 
Table 3. Diffusion coefficients for aqueous chlorhexidine digluconate solutions, $D_{\mathrm{CHDG}}$, at different concentrations, $C$, at temperature $T=298.15 \mathrm{~K}$ and pressure $P=101.3 \mathrm{kPa}$.

\begin{tabular}{ccc}
\hline$C /\left(\mathbf{m o l ~ d m}^{-3}\right)$ & $D_{\mathrm{CHDG}} /\left(\mathbf{1 0}^{-\mathbf{9}} \mathbf{~ m}^{\mathbf{2}} \mathbf{s}^{-\mathbf{1}}\right)$ & $D_{\mathrm{CHDG}, \mathrm{cf}} /\left(\mathbf{1 0 ^ { - 9 }} \mathbf{~ m}^{\mathbf{2}} \mathbf{s}^{-\mathbf{1}}\right)$ \\
\hline $0.000^{*}$ & $0.635 \pm 0.010$ & $0.762 \pm 0.016$ \\
0.001 & $0.617 \pm 0.009$ & $0.740 \pm 0.012$ \\
0.004 & $0.602 \pm 0.008$ & $0.677 \pm 0.013$ \\
\hline
\end{tabular}

* There is no CHDG in the flux and, consequently, the tracer diffusion coefficient is measured. The standard uncertainties are $u_{\mathrm{r}}(C)=0.03, u(T)=0.01 \mathrm{~K}, u(P)=2.03 \mathrm{kPa}$, and $u(D)=0.01 \times 10^{-9} \mathrm{~m}^{2} \mathrm{~s}^{-1}$.

Tracer diffusion coefficients of $\mathrm{CoCl}_{2}$ and $\mathrm{CrCl}_{3}$ and the mixture of them increase significantly in artificial saliva and in artificial saliva with $\mathrm{NaF} p H=7.0$, when compared with those obtained in water. The deviations between the tracer diffusion coefficient values $\left(D^{0}{ }_{1}\right)$ in these media and the limiting diffusion coefficients of these salts in water $\left(D^{0}\right)[31,32]$, at the same temperature, are positive $\left(\Delta D^{0} / D^{0}=44 \%, 62 \%\right.$, and $95 \%$, for $\mathrm{CoCl}_{2}$ and $\mathrm{CrCl}_{3}$, and the mixture of them, respectively). The increase in these $D^{0}$ values when compared with the $D^{0}$ value in water indicates the presence of salting-out effects. These ions, as chlorides, will suffer less frictional resistance to motion through the fluid and, consequently, their diffusion coefficients in these media become higher, and can flow faster inside living tissues, which can cause severe disturbances associated with these heavy metal ions.

However, in acidic media (artificial saliva $\mathrm{pH}=2.3$ with and without $\mathrm{NaF}$ ), tracer diffusion coefficient values are much smaller when compared with $D^{0}$ values in water. This fact may be explained on the basis of an electrostatic mechanism. Considering that in acid solutions, $\mathrm{H}_{3} \mathrm{O}^{+}$is one of the predominant species, due to its large mobility, a strong electric field will be generated by a concentration gradient in $\mathrm{H}^{+}$. Slowing down these $\mathrm{H}^{+}$ions drives large counter-current fluxes of $\mathrm{Co}^{2+}$ and $\mathrm{Cr}^{3+}$ in aqueous solutions, and consequently, their values of $D<0$ (salting-in). For $\mathrm{Cr}$ (III) solutions, an alteration in the structure of the solution due to modification of predominant species, as a function of $\mathrm{pH}$, is also expected.

Table 3 shows the average experimental diffusion coefficients of chlorhexidine digluconate in water and in a commercial formulation (cf). It is observed that the diffusion coefficients of CHDG at cf are higher than in water. In the case of salts, it has been found that $\mathrm{pH}$ is slightly lower than water and that has an effect in the tracer diffusion coefficients. Another possible explanation comes from the occurrence of higher ionic strength in the cf, thus inducing less electrostatic interactions between the diffusing species [33]. It can also be noticed that, in both cases, diffusion coefficients decrease by increasing the concentration; however, the effect of concentration in the diffusion of CHDG in the cf is more significant, when compared with water.

These results show that, although the interpretation of diffusion coefficients is not straightforward, they can provide relevant information on the effect of different conditions on the mobility of relevant ions, which can be of utmost importance for practical purposes. Keeping that in mind, ternary mutual diffusion coefficients for the systems $\left\{\left(\mathrm{CoCl}_{2}\right)(1)+\right.$ CHDG (2) $\}$ and $\left\{\left(\mathrm{CrCl}_{3}\right)(1)+\mathrm{CHDG}(2)\right\}$ in water and in a commercial formulation (cf), were measured at tracer concentrations, and data are reported in Tables 4 and 5, respectively.

Table 4. Tracer ternary diffusion coefficients $\left(D_{11}, D_{12}, D_{21}, D_{22}\right)$ of aqueous $\mathrm{CoCl}_{2}$ (or $\left.\mathrm{CrCl}_{3}\right)$ $\left(C_{1}=1 \times 10^{-3} \mathrm{~mol} \mathrm{dm}^{-3}\right)+\mathrm{CHDG}\left(C_{2}=0\right)$ solutions and at $T=298.15 \mathrm{~K}$ and $P=101.3 \mathrm{kPa}$.

\begin{tabular}{cccccc}
\hline & $\boldsymbol{D}_{\mathbf{1 1}} \pm \boldsymbol{S}_{\boldsymbol{D}}$ & $\boldsymbol{D}_{\mathbf{1 2}} \pm \boldsymbol{S}_{\boldsymbol{D}}$ & $\boldsymbol{D}_{\mathbf{2 1}} \pm \boldsymbol{S}_{\boldsymbol{D}}$ & $\boldsymbol{D}_{\mathbf{2 2}} \pm \boldsymbol{S}_{\boldsymbol{D}}$ & $\boldsymbol{D}_{\mathbf{1 2}} / \boldsymbol{D}_{\mathbf{2 2}}$ \\
\hline $\mathrm{CoCl}_{2}$ & $1.325 \pm 0.018$ & $-0.105 \pm 0.030$ & $-0.020 \pm 0.020$ & $0.780 \pm 0.010$ & -0.135 \\
$\mathrm{CrCl}_{3}$ & $1.310 \pm 0.020$ & $-0.205 \pm 0.030$ & $-0.050 \pm 0.010$ & $0.736 \pm 0.010$ & -0.279 \\
\hline
\end{tabular}

Diffusion coefficients and standard deviation, $S_{D}$, in units of $10^{-9} \mathrm{~m}^{2} \mathrm{~s}^{-1}$. The standard uncertainties are $u_{\mathrm{r}}(C)=0.03, u(D)=0.01 \times 10^{-9} \mathrm{~m}^{2} \mathrm{~s}^{-1}, u(T)=0.01 \mathrm{~K}$, and $u(P)=2.03 \mathrm{kPa}$. 
Table 5. Tracer ternary diffusion coefficients $\left(D_{11}, D_{12}, D_{21}, D_{22}\right)$ of aqueous $\mathrm{CoCl}_{2}$ (or $\mathrm{CrCl}_{3}$ ) $\left(C_{1}=1 \times 10^{-3} \mathrm{~mol} \mathrm{dm}^{-3}\right)+(\mathrm{CHDG}, c f)\left(C_{2}=0\right)$ solutions and at $T=298.15 \mathrm{~K}$ and $P=101.3 \mathrm{kPa}$.

\begin{tabular}{ccccccc}
\hline & $\boldsymbol{D}_{\mathbf{1 1}} \pm \boldsymbol{S}_{\boldsymbol{D}}$ & $\boldsymbol{D}_{\mathbf{1 2}} \pm \boldsymbol{S}_{\boldsymbol{D}}$ & $\boldsymbol{D}_{\mathbf{2 1}} \pm \boldsymbol{S}_{\boldsymbol{D}}$ & $\boldsymbol{D}_{\mathbf{2 2}} \pm \boldsymbol{S}_{\boldsymbol{D}}$ & $\boldsymbol{D}_{\mathbf{1 2}} / \boldsymbol{D}_{\mathbf{2 2}}$ & $\boldsymbol{D}_{\mathbf{2 1}} / \boldsymbol{D}_{\mathbf{1 1}}$ \\
\hline $\mathrm{CoCl}_{2}$ & $1.193 \pm 0.018$ & $-0.150 \pm 0.030$ & $-0.003 \pm 0.020$ & $0.809 \pm 0.010$ & -0.060 & -0.003 \\
$\mathrm{CrCl}_{3}$ & $1.309 \pm 0.020$ & $-1.080 \pm 0.030$ & $-0.002 \pm 0.010$ & $0.819 \pm 0.010$ & -1.201 & -0.001 \\
\hline
\end{tabular}

Diffusion coefficients and standard deviation, $S_{D}$, in units of $10^{-9} \mathrm{~m}^{2} \mathrm{~s}^{-1}$. The standard uncertainties are $u_{\mathrm{r}}(C)=0.03, u(D)=0.01 \times 10^{-9} \mathrm{~m}^{2} \mathrm{~s}^{-1}, u(T)=0.01 \mathrm{~K}$, and $u(P)=2.03 \mathrm{kPa}$.

Tracer diffusion coefficient values for chlorhexidine digluconate (at mole fraction $X_{2}=0$ ) are reported in Tables 4 and 5 . It should be noted that the main diffusion coefficients $D_{11}$ and $D_{22}$ were generally reproducible within $\pm 0.02 \times 10^{-9} \mathrm{~m}^{2} \mathrm{~s}^{-1}$, whilst the crosscoefficients were reproducible within $\pm 0.05 \times 10^{-9} \mathrm{~m}^{2} \mathrm{~s}^{-1}$.

The $D_{11}$ values are considerably larger than the $D_{22}$ values, and, in the case of $\mathrm{CrCl}_{3}$, they are higher than the binary diffusion coefficient of this salt measured previously by the same technique [31,32].

It can also be seen that coupled diffusion is significant. Indeed, $D_{21} / D_{11}$ ratios indicate that a mole of diffusing salt can counter-transport up to $0.6 \mathrm{~mol}$ of chlorhexidine digluconate, whereas the values of the ratio $D_{12} / D_{22}$ show that a mole of diffusing chlorhexidine can counter-transport up to $1.2 \mathrm{~mol}$ of salt $\left(\mathrm{CrCl}_{3}\right)$.

From the significant negative cross-diffusion coefficients for the system $\mathrm{CrCl}_{3}$ and chlorhexidine, indicating counter-current coupled flows of this salt and chlorhexidine digluconate, we can infer that there is evidence of strong interactions between these two components. This mechanism also accounts for the large negative values of cross-diffusion as well as the increased diffusivity of the $\mathrm{CrCl}_{3}$ and $\mathrm{CoCl}_{2}$ components in aqueous chlorhexidine digluconate (Tables 4 and 5). The presence of complex ions between $\mathrm{Co}$ (II) and $\mathrm{Cr}$ (III) ions and chlorhexidine digluconate may explain the obtaining of negative $D_{12}$ values. That is, in the region of the solution where the concentration of chlorhexidine digluconate is highest, there will be a more pronounced decrease of a large amount of the free $\mathrm{Co}^{2+}$ and $\mathrm{Cr}^{3+}$ ions resulting from the formation of those complex ions, hence the appearance of a gradient of these ions ( $\mathrm{Co}(\mathrm{II})$ or $\mathrm{Cr}(\mathrm{III}))$ with a signal opposite to the gradient of cobalt chloride (or chromium chloride).

Support for this effect of chlorhexidine digluconate on chromium ions was further assessed by UV-visible spectroscopy. Figure 2a shows the spectra of aqueous solutions of $\mathrm{CrCl}_{3} \cdot 6 \mathrm{H}_{2} \mathrm{O}$. The spectra show characteristics of maximum absorbances at 417 and $520 \mathrm{~nm}$ [34]. These spectra are similar to those obtained for $\mathrm{Cr}(\mathrm{III})$ in the presence of CHDG $(1 \mathrm{mM})$. However, an increase in the absorbance was found at both wavelengths: 417 and $590 \mathrm{~nm}$ (Figure 2b), accompanied by a maximum 0.2 and 0.05 red-shift displacement. No alteration in the spectra of Co(II) in the absence and presence of CHDG was observed (not shown). This can be justified by changes in the conjugated system of ligand molecules. The $\mathrm{Cr}$ (III) water exchange rate, from the first hydration shell, is very low [23], which confers some inert features for ligand substitution [35]; consequently, it can be hypothesized that a strong interaction with some component of $\mathrm{CHDG}$, acting as a ligand, takes place. Concomitantly, $\mathrm{Cr}$ (III) has high charge density when compared with $\mathrm{Co}(\mathrm{II})$ (the ionic radii of $\mathrm{Co}(\mathrm{II})$ and $\mathrm{Cr}$ (III) are 0.74 and $0.61 \mathrm{~nm}$, respectively [36]). The digluconate shows a high affinity towards metal ions (for example, calcium and aluminum) and, consequently, it could be the referred ligand $[37,38]$. 

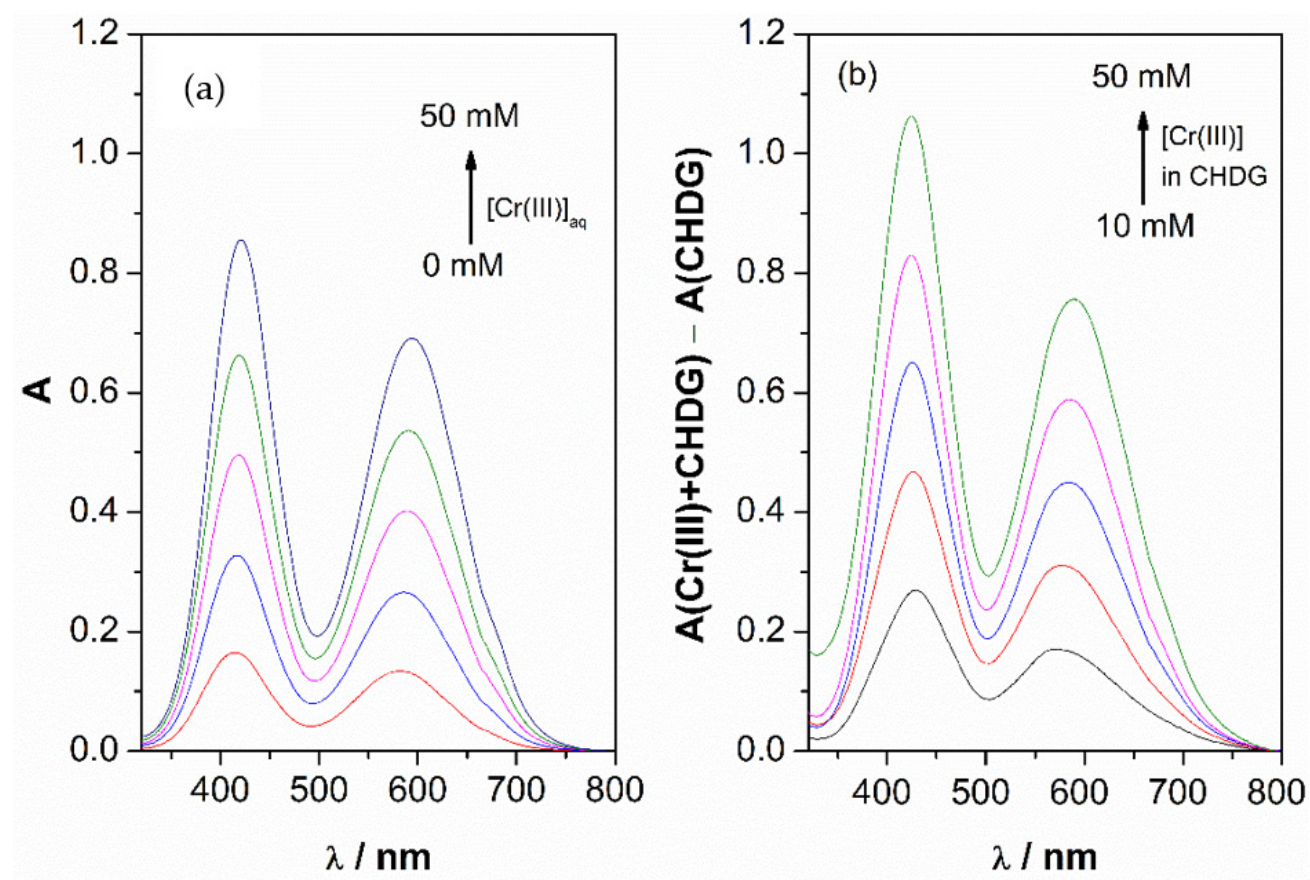

Figure 2. UV-vis spectra of aqueous solution of $\mathrm{CrCl}_{3}$ (a) and solutions of $\mathrm{CrCl}_{3}$ in chlorhexidine digluconate (b) (0.004 $\left.\mathrm{mol} \mathrm{dm}^{-3}\right)$.

\section{Materials and Methods}

\subsection{Materials}

Cobalt(II) chloride hexahydrate (Sigma-Aldrich, pro-analysis, purity (mass fraction) $>0.99$, Lyon, France), chromium(III) chloride hexahydrate (Riedel-de-Haen, pro-analysis $>97 \%$, Seelze, Germany), and chlorhexidine digluconate solution (20\% in water, Sigma-Aldrich, Lyon, France) were used as received without further purification (Table 6).

Table 6. Sample description.

\begin{tabular}{|c|c|c|c|}
\hline Chemical & Source & CAS Number & Mass Fraction Purity \\
\hline $\mathrm{CoCl}_{2} \cdot 6 \mathrm{H}_{2} \mathrm{O}$ & Sigma-Aldrich & $7791-13-1$ & $>0.98^{(\mathrm{a})}$ \\
\hline $\mathrm{CrCl}_{3} \cdot 6 \mathrm{H}_{2} \mathrm{O}$ & Riedel-de-Haen, Seelze & $10060-12-5$ & $>0.98^{\text {(a) }}$ \\
\hline $\mathrm{NaF}$ & Sigma-Aldrich & & $>0.99^{\text {(a) }}$ \\
\hline Lactic acid & Sigma-Aldrich & & $>0.85$ wt. $\%$ (a) \\
\hline Artificial saliva $^{(\mathrm{b})}$ & & & \\
\hline Chlorhexidine digluconate $^{(\mathrm{c})}$ & Sigma-Aldrich & $18472-51-0$ & $20 \%$ in water \\
\hline $\mathrm{H}_{2} \mathrm{O}$ & $\begin{array}{c}\text { Millipore-Q water } \\
\left(1.82 \times 10^{5} \Omega \mathrm{m} \text { at } 298.15 \mathrm{~K}\right)\end{array}$ & $7732-18-5$ & \\
\hline
\end{tabular}

(a) As stated by the supplier. ${ }^{(b)}$ Artificial saliva was prepared according to the following composition $[39,40]$ potassium chloride $(\mathrm{KCl}, 20 \mathrm{mmol} / \mathrm{L})$, sodium hydrogenocarbonate $\left(\mathrm{NaHCO}_{3}, 17.9 \mathrm{mmol} / \mathrm{L}\right)$, sodium phosphate $\left(\mathrm{NaH}_{2} \mathrm{PO}_{4} \cdot \mathrm{H}_{2} \mathrm{O}, 3.6 \mathrm{mmol} / \mathrm{L}\right)$, potassium thiocyanate $(\mathrm{KSCN}, 5.1 \mathrm{mmol} / \mathrm{L})$, and lactic acid $(0.10 \mathrm{mmol} / \mathrm{L}) .{ }^{\text {(c) }} \mathrm{In}$ this work, a commercial formulation containing $0.2 \%$ chlorhexidine digluconate was also used.

The solutions needed for diffusion measurements were prepared in calibrated volumetric glass flasks, using as solvents: ultrapure water (Millipore, Germany, Milli-Q Advantage A10, specific resistance $=1.82 \times 10^{5} \Omega \mathrm{m}$, at $298.15 \mathrm{~K}$ ), artificial saliva, prepared according the composition indicated in Table 6, and a commercially available Extra Eludril ${ }^{\circledR}$ from Pierre Fabre Oral Care, with $0.2 \%$ chlorhexidine digluconate.

The weighing was performed using a Radwag AS 220C2 balance with readability of $10^{-5} \mathrm{~g}$ in the lower range.

The $\mathrm{pH}$ measurements of solutions were carried out with a Radiometer $\mathrm{pH}$ meter PHM 240 with an Ingold U457-K7pH conjugated electrode. $\mathrm{pH}$ was measured in fresh solutions, and the electrode was calibrated immediately before each experimental set of 
solutions using IUPAC-recommended $\mathrm{pH} 4,7$, and 10 buffers. From $\mathrm{pH}$ meter calibration, a zero-pH of $6.897 \pm 0.030$ and sensitivity higher than $98.7 \%$ were obtained. To perform these measurements at $\mathrm{pH} 2.3$ and 7.0, the intended values of the $\mathrm{pH}$ were adjusted by the addition of lactic acid. All solutions were freshly prepared at $298.15 \mathrm{~K}$ and degassed by sonication for about $60 \mathrm{~min}$ before each experiment.

\subsection{Taylor Method}

\subsubsection{Tracer Diffusion Coefficients}

We consider the system containing cobalt chloride (or chromium chloride) in artificial saliva as a pseudo-binary system. That is, a system with two components, $\mathrm{Co}$ (II) or $\mathrm{Cr}$ (III), and $\mathrm{Cl}^{-}$ions, assuming the artificial saliva (with and without lactic acid and sodium fluoride components) as a mixed solvent.

The diffusion coefficient, $D$, in these pseudo-binary systems may be defined in terms of the concentration gradient by the phenomenological relationship of Fick's first law (Equation (1)):

$$
J=-D \nabla C
$$

where $J$ and $\nabla C$ are the molar flux and the gradient in the concentration of solute, respectively.

In addition, the ionic strength of the artificial saliva is significantly higher than the salt concentration under study $\left(\mathrm{CoCl}_{2} 0.001 \mathrm{~mol} \mathrm{dm}^{-3}\right.$ or $\left.\mathrm{CrCl}_{3} 0.001 \mathrm{~mol} \mathrm{dm}^{-3}\right)$ (that is, approximately $0.075 \mathrm{~mol} \mathrm{dm}^{-3}$ ), ensuring the occurrence of tracer diffusion, and the composition of saliva in the injection and carrier solutions are equal. This is also confirmed by the detector signal resembling a single normal distribution with variance $r^{2} t_{R} / 24 D_{T}$, and not two overlapping normal distributions [17]. We may consider the system as pseudobinary and consequently take the measured parameters as the tracer diffusion coefficients of the $\mathrm{CoCl}_{2}\left(\right.$ or $\left.\mathrm{CrCl}_{3}\right)$ in the artificial saliva.

The Taylor dispersion method is based on the dispersion of small amounts of solution injected into laminar carrier streams of water or solution of different composition, flowing through a long capillary tube (Figure 3). Since the detailed description of this method can be found in the literature (e.g., $[17,18,41-43])$, only a few more relevant points are highlighted here.

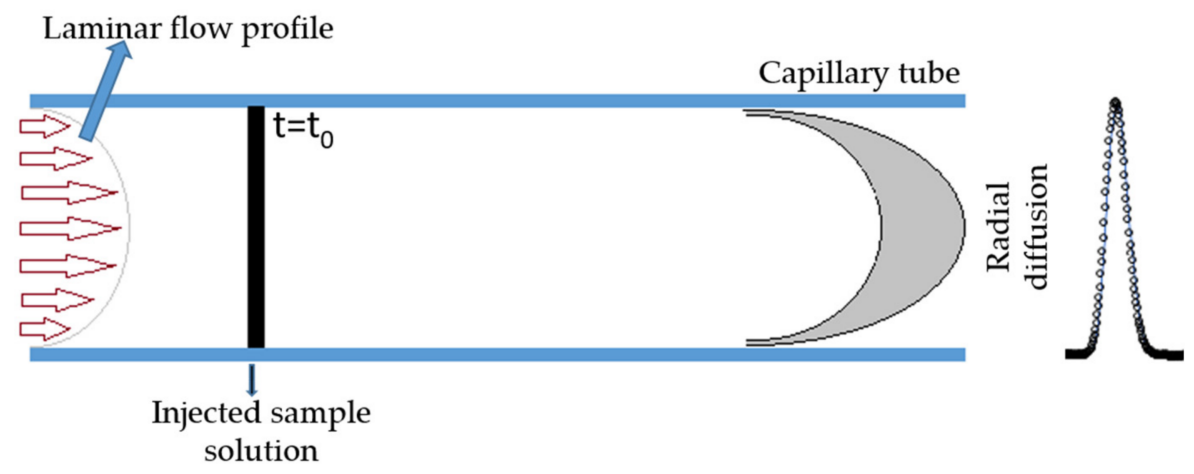

Figure 3. Schematic representation of the dispersion technique.

The length of the dispersion tube (PTFE) used in the present study was measured directly by stretching the tube in a reservoir and using two high-quality theodolytes and appropriate mirrors to accurately focus on the tube ends. This technique afforded a tube length of $3.2799( \pm 0.0001) \times 10^{4} \mathrm{~mm}$, in agreement with less-precise control measurements using a good-quality measuring tape. The radius of the tube, $0.5570( \pm 0.00003) \mathrm{mm}$, was calculated from the tube volume obtained by accurately weighing (resolution $0.1 \mathrm{mg}$ ) the tube when empty and when filled with distilled water of known density. The tube was mounted on a rigid cylindrical support in side-by-side coils of $200 \mathrm{~mm}$ radius. 
At the start of each run, a 6-port poly(tetrafluoroethylene) injection valve (Rheodyne, model 5020) was used to introduce $0.063 \mathrm{~mL}$ of solution into the laminar carrier stream of slightly different composition. A flow rate of $0.17 \mathrm{~mL} \mathrm{~min}^{-1}$ was maintained by a metering pump (Gilson model Minipuls 3) to give retention times of about $1.1 \times 10^{4} \mathrm{~s}$. The dispersion tube and the injection valve were kept at $298.15 \mathrm{~K}( \pm 0.01 \mathrm{~K})$ in an air thermostat.

Dispersion of the injected samples was monitored using a differential refractometer (Waters model 2410) at the outlet of the dispersion tube. Detector voltages, $V(t)$, were measured at precisely $5 \mathrm{~s}$ intervals with a digital voltmeter (Agilent $34401 \mathrm{~A}$ ) with an IEEE interface. Binary diffusion coefficients were evaluated by fitting the dispersion equation:

$$
V(t)=V_{0}+V_{1} t+V_{\max }\left(t_{\mathrm{R}} / t\right)^{1 / 2} \exp \left[-12 D\left(t-t_{\mathrm{R}}\right)^{2} / r^{2} t\right]
$$

to the detector voltages. The additional fitting parameters are the mean sample retention time, $t_{\mathrm{R}}$, peak height, $V_{\max }$, baseline voltage, $V_{0}$, and baseline slope, $V_{1}$.

\subsubsection{Diffusion of Chlorhexidine Digluconate}

The diffusion behavior of aqueous solutions of chlorhexidine digluconate at different concentrations without added salts was analyzed. The dispersion profiles were prepared by injecting water into carrier streams of chlorhexidine digluconate $0.2 \%$, and by injecting chlorhexidine digluconate of composition $0.2 \%$ and $0.04 \%(\mathrm{~m} / \mathrm{v})$ into water. Although chlorhexidine digluconate $0.2 \%$ was accompanied by other substances, the resulting aqueous systems were assumed as pseudo-binaries. The respective diffusion coefficients were measured for the same procedure described in the preceding Section 3.1, and evaluated by fitting the dispersion equation (Equation (2)).

The effect of chlorhexidine digluconate on the diffusion of cobalt and chromium ions was investigated by using Taylor dispersion to measure the ternary mutual diffusion coefficients $\left(D_{\mathrm{ik}}\right)$ of aqueous $\mathrm{CoCl}_{2}\left(\right.$ or $\left.\mathrm{CrCl}_{3}\right)\left(C_{1}\right)+$ chlorhexidine digluconate $\left(C_{2}\right)$ solutions and using coupled Fick equations (Equations (3) and (4)) [44,45]:

$$
\begin{aligned}
& J_{1}=-D_{11} \nabla C_{1}-D_{12} \nabla C_{2} \\
& J_{2}=-D_{21} \nabla C_{1}-D_{22} \nabla C_{2}
\end{aligned}
$$

where $J_{1}$ and $J_{2}$ are the molar fluxes of $\mathrm{CoCl}_{2}$ (or $\mathrm{CrCl}_{3}$ ) (component 1 ) and chlorhexidine digluconate (component 2 ) driven by the concentration gradients, $\nabla C_{1}$ and $\nabla C_{2}$, of each solute 1 and 2 , respectively. $D_{11}$ and $D_{22}$ are the main, whilst $D_{12}$ and $D_{21}$ are the crossdiffusion coefficients. For more details see, for example, [29].

In the present work, pseudo-ternary dispersion profiles were prepared by injecting $\mathrm{CoCl}_{2}$ (or $\mathrm{CrCl}_{3}$ ) (component 1) + chlorhexidine digluconate (component 2) solution samples of composition $\bar{C}_{1}+\Delta C_{1}, \bar{C}_{2}$ into carrier streams of composition $\bar{C}_{2}$, and by injecting $\mathrm{CoCl}_{2}$ (or $\mathrm{CrCl}_{3}$ ) (component 1$)+$ chlorhexidine digluconate (component 2) solution samples of composition $\bar{C}_{1}, \bar{C}_{2}+\Delta C_{2}$ into carrier streams of composition $\bar{C}_{1}$ Coupled diffusion produces ternary dispersion profiles (Equations (5) and (6)):

$$
\begin{gathered}
V=\bar{V}+V_{1}+V_{\max } \sqrt{\frac{t_{\mathrm{R}}}{t}} \frac{\left(a+b \alpha_{1}\right) \sqrt{D_{1}} e^{-12 D_{1}\left(t-t_{\mathrm{R}}\right)^{2} / r^{2} t}+\left(1-a-b \alpha_{1}\right) \sqrt{D_{2}} e^{-12 D_{2}\left(t-t_{\mathrm{R}}\right)^{2} / r^{2} t}}{\left(a+b \alpha_{1}\right) \sqrt{D_{1}}+\left(1-a-b \alpha_{1}\right) \sqrt{D_{2}}} \\
\alpha_{1}=\frac{R_{1} \Delta C_{1}}{R_{1} \Delta C_{1}+R_{2} \Delta C_{2}}
\end{gathered}
$$

where $D_{1}$ and $D_{2}$ are the eigenvalues of the matrix of ternary $D_{\mathrm{ik}}$ coefficients (Equations (7) and (8)) and $\alpha_{1}$ is the fraction of the initial refractive index difference due to $\mathrm{CoCl}_{2}$ (or $\left.\mathrm{CrCl}_{3}\right) . R_{1}$ and $R_{2}$ are the detector sensitivities for $\mathrm{CoCl}_{2}\left(\right.$ or $\left.\mathrm{CrCl}_{3}\right)$ (1) and chlorhexidine digluconate (2): $R_{1}=\partial V / \partial C_{1}$ and $R_{2}=\partial V / \partial C_{2}$.

$$
D_{1}=\left\{D_{11}+D_{22}+\left(D_{11}-D_{22}\right) \sqrt{1+\left[4 D_{12} D_{21} /\left(D_{11}-D_{22}\right)^{2}\right]}\right\} / 2
$$




$$
D_{2}=\left\{D_{11}+D_{22}-\left(D_{11}-D_{22}\right) \sqrt{1+\left[4 D_{12} D_{21} /\left(D_{11}-D_{22}\right)^{2}\right]}\right\} / 2
$$

Ternary mutual diffusion coefficients were calculated from $D_{1}, D_{2}, a$, and $b$ fitting parameters and the relative detector sensitivity, $R_{2} / R_{1}$, using:

$$
\begin{gathered}
D_{11}=D_{1}+\frac{a(1-a-b)}{b}\left(D_{1}-D_{2}\right) \\
D_{12}=\frac{R_{2}}{R_{1}} \frac{a(1-a)}{b}\left(D_{1}-D_{2}\right) \\
D_{21}=\frac{R_{1}}{R_{2}} \frac{(a+b)(1-a-b)}{b}\left(D_{2}-D_{1}\right) \\
D_{22}=D_{2}+\frac{a(1-a-b)}{b}\left(D_{2}-D_{1}\right)
\end{gathered}
$$

$a$ and $b$ parameters in Equations (9)-(12) are described by:

$$
\begin{gathered}
a=\frac{D_{11}-D_{1}-\left(R_{1} / R_{2}\right) D_{12}}{D_{2}-D_{1}} \\
b=\frac{D_{22}-D_{11}+\left(R_{1} / R_{2}\right) D_{12}-\left(R_{2} / R_{1}\right) D_{21}}{D_{2}-D_{1}}
\end{gathered}
$$

\subsection{UV-Vis Spectroscopy Measurements}

Electronic absorption spectroscopy of solutions of $\mathrm{Cr}(\mathrm{III})$ and $\mathrm{Co}(\mathrm{II})$, in the concentration range $10-50 \mathrm{mM}$, in water and in a mixture containing chlorohexidine digluconate, was carried out by using a Shimadzu UV-2600i UV-Vis spectrophotometer.

\section{Conclusions}

Binary and ternary diffusion coefficients of cobalt chloride and chromium chloride, and chlorohexidine digluconate, alone and in mix solutions, respectively, were measured by the Taylor dispersion technique. In artificial saliva at $\mathrm{pH}=2.3$, containing lactic acid and sodium fluoride, a decrease of the diffusion coefficients of these salts from approximately $10 \%$ to $40 \%$ was observed when compared with those obtained in water. In the presence of saliva, a salting-in effect affecting the metal ion salts was observed.

However, in artificial saliva at $\mathrm{pH}=7$ and 8.0, the diffusion coefficients of these salts increased significantly (at most 60\%), which indicates the presence of salting-out effects. These ions will suffer less frictional resistance to motion through the fluid and, consequently, their diffusion coefficients in these media become higher and can flow faster inside living tissues, causing severe disturbances associated with these heavy metal ions.

Interactions between the metal salts and CHDG were also observed, essentially for $\mathrm{Cr}(\mathrm{III})$, by UV-Vis spectroscopy.

The experimental results suggested that interactions between metal ions and CHDG might be justified by the occurrence of metal-digluconate interactions and are stronger for $\mathrm{Cr}(\mathrm{III})$, probably due to its high charge density.

We can conclude that the chlorhexidine digluconate may be used as a controlled heavy metal chromium and cobalt capture system, and therefore contribute to reduce the toxicity levels in the oral cavity.

Author Contributions: Conceptualization, A.C.F.R., A.J.M.V., and M.A.E.; Data curation, S.I.G.F., P.M.G.N., F.A.D.R.A.G., M.M.R., A.C.F.R., and A.J.M.V.; Funding acquisition, A.C.F.R., and M.A.E.; Investigation, S.I.G.F., M.M.R., G.U., A.M.T.D.P.V.C., and A.C.F.R.; Methodology, S.I.G.F., P.M.G.N., F.A.D.R.A.G., G.U., M.M.R., A.M.T.D.P.V.C., A.C.F.R., A.J.M.V., and M.A.E.; Project administration, A.C.F.R., and M.A.E.; Resources, A.C.F.R., and M.A.E.; Supervision, A.C.F.R., A.J.M.V., and M.A.E.; Validation, S.I.G.F., A.C.F.R., A.J.M.V., and M.A.E.; Visualization, A.C.F.R., A.J.M.V., and M.A.E.; 
Writing—original draft, S.I.G.F., G.U., A.C.F.R., and M.A.E.; Writing—review and editing, A.C.F.R., A.J.M.V., and M.A.E. All authors have read and agreed to the published version of the manuscript.

Funding: This research was funded by Fundação para a Ciência e a Tecnologia (FCT) through COMPETE Programme (Operational Programme for Competitiveness), grant number UIDB/QUI/00313/2020.

Institutional Review Board Statement: Not applicable.

Informed Consent Statement: Not applicable.

Data Availability Statement: Data are contained within the article.

Acknowledgments: We are thankful to António M.C. Ferreira for the technical support for diffusion technique maintenance. The authors are grateful for funding from "The Coimbra Chemistry Centre" which is supported by the Fundação para a Ciência e a Tecnologia (FCT), Portuguese Agency for Scientific Research, through the projects UIDB/QUI/UI0313/2020 and COMPETE Programme (Operational Programme for Competitiveness), and CIROS, Centro de Investigação e Inovação em Ciências Dentárias da FMUC. G.U. thanks FCT, Portugal, for PhD grant (SFR/BD/146358/2019).

Conflicts of Interest: The authors declare no conflict of interest.

\section{References}

1. Arregui, M.; Latour, F.; Gil, F.J.; Pérez, R.A.; Giner-Tarrida, L.; Delgado, L.M. Ion Release from Dental Implants, Prosthetic Abutments and Crowns under Physiological and Acidic Conditions. Coatings 2021, 11, 98. [CrossRef]

2. Kassapidou, M.; Hjalmarsson, L.; Johansson, C.B.; Hammarström Johansson, P.; Morisbak, E.; Wennerberg, A.; Franke Stenport, V. Cobalt-chromium alloys fabricated with four different techniques: Ion release, toxicity of released elements and surface roughness. Dent. Mater. 2020, 36, e352-e363. [CrossRef]

3. Wang, G.; Zreiqat, H. Functional Coatings or Films for Hard-Tissue Applications. Materials 2010, 3, 3994-4050. [CrossRef] [PubMed]

4. Asri, R.I.M.; Harun, W.S.W.; Samykano, M.; Lah, N.A.C.; Ghani, S.A.C.; Tarlochan, F.; Raza, M.R. Corrosion and surface modification on biocompatible metals: A review. Mater. Sci. Eng. C 2017, 77, 1261-1274. [CrossRef]

5. Hanawa, T. Titanium-Tissue Interface Reaction and Its Control with Surface Treatment. Front. Bioeng. Biotechnol. 2019, 7, 170. [CrossRef] [PubMed]

6. Reclaru, L.; Cosmina Ardelean, L.; Florian Grecu, A.; Adrian Miu, C. Multicomponent Alloys for Biomedical Applications. In Engineering Steels and High Entropy-Alloys; IntechOpen: London, UK, 2020.

7. Mulware, S.J. Trace elements and carcinogenicity: A subject in review. 3 Biotech 2013, 3, 85-96. [CrossRef] [PubMed]

8. Zhao, J.; Castranova, V. Toxicology of Nanomaterials Used in Nanomedicine. J. Toxicol. Environ. Health Part B 2011, 14, 593-632. [CrossRef]

9. Mihardjanti, M.; Ismah, N.; Purwanegara, M.K. Nickel and chromium ion release from stainless steel bracket on immersion various types of mouthwashes. J. Phys. Conf. Ser. 2017, 884, 012107. [CrossRef]

10. Shruthi, D.; Patil, G.; Prithviraj, D. Comparative evaluation of ion release in bonded and nonbonded stainless steel brackets with use of different mouthwashes: An In vitro study. Contemp. Clin. Dent. 2020, 11, 15. [CrossRef]

11. Noumbissi, S.; Scarano, A.; Gupta, S. A Literature Review Study on Atomic Ions Dissolution of Titanium and Its Alloys in Implant Dentistry. Materials 2019, 12, 368. [CrossRef]

12. Mathew, M.T.; Srinivasa Pai, P.; Pourzal, R.; Fischer, A.; Wimmer, M.A. Significance of Tribocorrosion in Biomedical Applications: Overview and Current Status. Adv. Tribol. 2009, 2009, 250986. [CrossRef]

13. Zhu, M.H.; Cai, Z.B.; Li, W.; Yu, H.Y.; Zhou, Z.R. Fretting in prosthetic devices related to human body. Tribol. Int. 2009, 42, 1360-1364. [CrossRef]

14. Zheng, Y.; Bashandeh, K.; Shakil, A.; Jha, S.; Polycarpou, A.A. Review of dental tribology: Current status and challenges. Tribol. Int. 2022, 166, 107354. [CrossRef]

15. Vaicelyte, A.; Janssen, C.; Le Borgne, M.; Grosgogeat, B. Cobalt-Chromium Dental Alloys: Metal Exposures, Toxicological Risks, CMR Classification, and EU Regulatory Framework. Crystals 2020, 10, 1151. [CrossRef]

16. Taylor, G.I. Dispersion of soluble matter in solvent flowing slowly through a tube. Proc. R. Soc. London Ser. A Math. Phys. Sci. 1953, 219, 186-203. [CrossRef]

17. Callendar, R.; Leaist, D.G. Diffusion Coefficients for Binary, Ternary, and Polydisperse Solutions from Peak-Width Analysis of Taylor Dispersion Profiles. J. Solut. Chem. 2006, 35, 353-379. [CrossRef]

18. Loh, W. A técnica de dispersão de taylor para estudos de difusão em líquidos e suas aplicações. Quim. Nova 1997, 20, 541-545. [CrossRef]

19. Suito, H.; Iwawaki, Y.; Goto, T.; Tomotake, Y.; Ichikawa, T. Oral Factors Affecting Titanium Elution and Corrosion: An In Vitro Study Using Simulated Body Fluid. PLoS ONE 2013, 8, e66052. [CrossRef]

20. Edgar, W.M.; O'Mullane, D.M. Saliva and Oral Health, 2nd ed.; British Dental Association: London, UK, 1996 ; ISBN 0904588475. 
21. Puskar, T.; Jevremovic, D.; Williams, R.; Eggbeer, D.; Vukelic, D.; Budak, I. A Comparative Analysis of the Corrosive Effect of Artificial Saliva of Variable pH on DMLS and Cast Co-Cr-Mo Dental Alloy. Materials 2014, 7, 6486-6501. [CrossRef]

22. Ribeiro, A.C.F.; Lobo, V.M.M.; Natividade, J.J.S. Diffusion Coefficients in Aqueous Solutions of Cobalt Chloride at 298.15 K. J. Chem. Eng. Data 2002, 47, 539-541. [CrossRef]

23. Baes, C.F., Jr.; Mesmer, R.E. The Hydrolysis of Cations; John Wiley \& Sons, Inc.: New York, NY, USA, 1976.

24. Stuenzi, H.; Marty, W. Early stages of the hydrolysis of chromium(III) in aqueous solution. 1. Characterization of a tetrameric species. Inorg. Chem. 1983, 22, 2145-2150. [CrossRef]

25. Jafari, K.; Rahimzadeh, S.; Hekmatfar, S. Nickel ion release from dental alloys in two different mouthwashes. J. Dent. Res. Dent. Clin. Dent. Prospects 2019, 13, 19-23. [CrossRef] [PubMed]

26. Rugg-Gunn, A. Fluoride toothpastes and fluoride mouthrinses. Acta Med. Acad. 2013, 42, 168-178. [CrossRef] [PubMed]

27. Mabilleau, G.; Bourdon, S.; Joly-Guillou, M.L.; Filmon, R.; Baslé, M.F.; Chappard, D. Influence of fluoride, hydrogen peroxide and lactic acid on the corrosion resistance of commercially pure titanium. Acta Biomater. 2006, 2, 121-129. [CrossRef] [PubMed]

28. Takemoto, S.; Hattori, M.; Yoshinari, M.; Kawada, E.; Oda, Y. Corrosion behavior and surface characterization of titanium in solution containing fluoride and albumin. Biomaterials 2005, 26, 829-837. [CrossRef]

29. Musilová, L.; Mráček, A.; Kašpárková, V.; Minařík, A.; Valente, A.J.M.; Azevedo, E.F.G.; Veríssimo, L.M.P.; Rodrigo, M.M.; Esteso, M.A.; Ribeiro, A.C.F. Effect of Hofmeister Ions on Transport Properties of Aqueous Solutions of Sodium Hyaluronate. Int. J. Mol. Sci. 2021, 22, 1932. [CrossRef]

30. Melia Rodrigo, M.; Ribeiro, A.C.F.; Moço, G.; Cabral, A.M.T.D.P.V.; Valente, A.J.M.; Esteso, M.A.; Abreu, P.E.; Santos, J.R.C.; Marques, J.M.C. Effect of sodium chloride on the behaviour of the lactose in aqueous solution studied from diffusion experiments and molecular dynamics simulations. J. Chem. Thermodyn. 2021, 155, 106370. [CrossRef]

31. Ribeiro, A.C.F.; Barros, M.C.F.; Veríssimo, L.M.P.; Santos, C.I.A.V.; Cabral, A.M.T.D.P.V.; Gaspar, G.D.; Esteso, M.A. Diffusion coefficients of paracetamol in aqueous solutions. J. Chem. Thermodyn. 2012, 54, 97-99. [CrossRef]

32. Ribeiro, A.C.F.; Lobo, V.M.M.; Oliveira, L.R.C.; Burrows, H.D.; Azevedo, E.F.G.; Fangaia, S.I.G.; Nicolau, P.M.G.; Guerra, F.A.D.R.A. Diffusion Coefficients of Chromium Chloride in Aqueous Solutions at 298.15 K and 303.15 K. J. Chem. Eng. Data 2005, 50, 1014-1017. [CrossRef]

33. Kittner, M.; Klapp, S.H.L. Screening effects on structure and diffusion in confined charged colloids. J. Chem. Phys. 2007, 126, 154902. [CrossRef] [PubMed]

34. Scattergood, P.A. Recent Advances in Chromium Coordination Chemistry: Luminescent Materials and Photocatalysis. In Organometallic Chemistry; Patmore, N.J., Elliott, P.I.P., Eds.; Royal Society of Chemistry: London, UK, 2020; Volume 43, pp. 1-34 [CrossRef]

35. Costa, D.; Pais, A.A.C.C.; Bastos, M.; Bai, G.; Miguel, M.d.G.; Ramos, M.L.; Valente, A.J.M.; Burrows, H.D.; Teixeira, M.H. Does cation dehydration drive the binding of metal ions to polyelectrolytes in water? What we can learn from the behaviour of aluminium(iii) and chromium(iii). Phys. Chem. Chem. Phys. 2012, 14, 7950. [CrossRef]

36. Jiménez, J.-R.; Doistau, B.; Poncet, M.; Piguet, C. Heteroleptic trivalent chromium in coordination chemistry: Novel building blocks for addressing old challenges in multimetallic luminescent complexes. Coord. Chem. Rev. 2021, 434, 213750. [CrossRef]

37. Sawyer, D.T. Metal-Gluconate Complexes. Chem. Rev. 1964, 64, 633-643. [CrossRef]

38. Buckó, Á.; Kutus, B.; Peintler, G.; Kele, Z.; Pálinkó, I.; Sipos, P. Stability and structural aspects of complexes forming between aluminum(III) and D-heptagluconate in acidic to strongly alkaline media: An unexpected diversity. J. Mol. Liq. 2020, 314, 113645. [CrossRef]

39. Marek, M. Dissolution of Mercury from Dental Amalgam at Different pH Values. J. Dent. Res. 1997, 76, 1308-1315. [CrossRef] [PubMed]

40. Horasawa, N.; Takahashi, S.; Marek, M. Galvanic interaction between titanium and gallium alloy or dental amalgam. Dent. Mater. 1999, 15, 318-322. [CrossRef]

41. Barthel, J.; Gores, H.J.; Lohr, C.M.; Seidl, J.J. Taylor dispersion measurements at low electrolyte concentrations. I. Tetraalkylammonium perchlorate aqueous solutions. J. Solut. Chem. 1996, 25, 921-935. [CrossRef]

42. Lopes, M.L.S.M.; Nieto de Castro, C.A.; Sengers, J.V. Mutual diffusivity of a mixture of normal-hexane and nitrobenzene near its consolute point. Int. J. Thermophys. 1992, 13, 283-294. [CrossRef]

43. Alizadeh, A.; Nieto de Castro, C.A.; Wakeham, W.A. The theory of the Taylor dispersion technique for liquid diffusivity measurements. Int. J. Thermophys. 1980, 1, 243-284. [CrossRef]

44. Price, W.E. Theory of the taylor dispersion technique for three-component-system diffusion measurements. J. Chem. Soc. Faraday Trans. 1 Phys. Chem. Condens. Phases 1988, 84, 2431. [CrossRef]

45. Deng, Z.; Leaist, D.G. Ternary mutual diffusion coefficients of $\mathrm{MgCl}_{2}+\mathrm{MgSO}_{4}+\mathrm{H}_{2} \mathrm{O}$ and $\mathrm{Na}_{2} \mathrm{SO}_{4}+\mathrm{MgSO}_{4}+\mathrm{H}_{2} \mathrm{O}$ from Taylor dispersion profiles. Can. J. Chem. 1991, 69, 1548-1553. [CrossRef] 